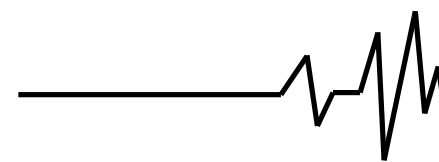

Граняк В. Ф.

к.т.н., доцент

Гайдамак О. Л.

к.т.н., доцент

Вінницький національний аграрний університет

Granyak V.

$\mathrm{PhD}$, associate professor

\section{Gaidamak 0.}

$\mathrm{PhD}$, associate professor

Vinnytsia National Agrarian University
УДК 621.3

DOI: 10.37128/2306-8744-2021-2-7

ВИКОРИСТАННЯ ДИСКРЕТНОГО ВЕЙВЛЕТ-АНАЛІЗУ ВІБРОАКУСТИЧНОГО СИГНАЛУ ДЛЯ ВИЯВЛЕННЯ АСИМЕТРІЇ ЖИВЛЕННЯ ОБЕРТОВИХ ЕЛЕКТРИЧНИХ МАШИН ЗМІННОГО
СТРУМУ

у роботі показано що серед існуючих достатньо описаних та вивчених підходів, придатних для аналізу часової реалізації вібросигналу, який може бути отриманий під час роботи реальної електричної машини, можна виділити перетворення Фур'є та дискретне вейвлет-перетворення. Аналіз наведених у літературі описів вібро-акустичних сигналів, обумовлених асиметрією живлення, показує, що зазначений дефрект призводить до появи коливань, які містять гармонічну складову, локалізовану на частоті напруги живлення електричної мережі. Зазначений фракт обґрунтовує доцільність аналізу частотного діапазону, що включає у себе частоту напруги живлення, та підбір материнського вейвлету, виходячи з ознак, властивих одиничному гармонічному коливанню.

Запропоновано спосіб виявлення дефекту асиметрії живлення обертових електричних машин змінного струму за допомогою дискретного вейвлет-перетворення їх віброакустичного сигналу. Встановлено частотну смугу, що доцільно аналізувати з метою виявлення зазначеного дефекту.

Встановлено, що виявлення дефекту асиметрії живлення з використанням вейвлет-перетворення часової реалізації вібро-акустичного сигналу доцільно здійснювати за використанням материнської вейвлет-фрункції Хаара, що забезпечує поєднання високого ступеня спорідненості материнського вейвлету з формою зміни вібросигналу за рахунок асиметрії живлення та відносної простоти такого перетворення.

Показано, що при виявлені асиметрії живлення доцільно здійснювати аналіз поведінки вейвлет коефіцієнтів частотної смуги, що включає $y$ себе частоту напруги живлення електричної машини. Оскільки вплив зазначеного дефекту на інші частотні смуги буде мінімальним, то аналіз поведінки їх коефріцієнтів вейвлет перетворення з метою виявлення зазначеного дефректу є неефективним.

Запропоновано числовий критерій оцінки впливу асиметрії живлення на коефріцієнти вейвлет-перетворення у вигляді середньо квадратичного значення вейвлет коефріцієнтів інформативної частотної смуги при дослідженні часового інтервалу, що значно перевищує період напруги живлення електричної машини. Показано, що зазначений критерій має понижену чутливість до впливу неінформативних одиничних збурень, які можуть виникати в процесі роботи електричної машини.

Ключові слова: електрична машина, дебаланс ротора, дефект, сплеск, вейвлет-перетворення. 


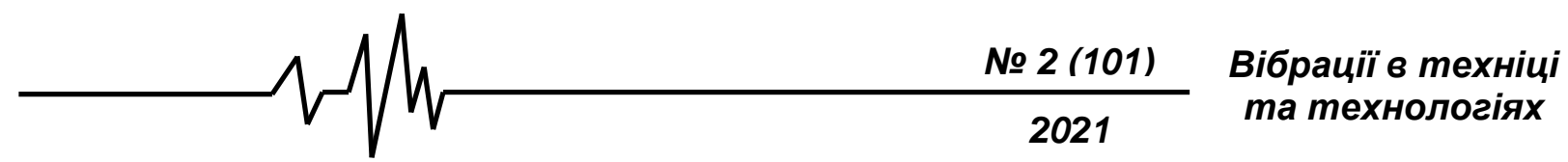

Вступ. На сьогоднішній день склалася стійка тенденція до побудови систем технічного контролю та діагностування силових електричних машин на основі аналізу їх вібро-акустичних характеристик. Це пов'язано як 3 їх високими чутливістю та інформативністю, так і 3 можливістю вимірювання вказаного параметру безпосередньо у режимі роботи електричної машини без необхідності суттєвого втручання у ії конструкцію [1, 2]. Про те, здійснення такого аналізу потребує розв'язання ряду науковоприкладних задач, які випливають з особливостей вібро-акустичного сигналу, який виникає при роботі електричних машин. Зокрема, у складі такого сигналу містяться як періодичні складові різної частоти, так і аперіодичні (пікові) складові, обумовлені наявністю дефектів різної природи та іншими періодичними і аперіодичними збурюючими силами [3, 4].

\section{Аналіз останніх досліджень.}

Серед існуючих достатньо описаних та вивчених підходів, придатних для аналізу часової реалізації вібросигналу, який може бути отриманий під час роботи реальної електричної машини, можна виділити перетворення Фур'є та дискретне вейвлет-перетворення (ДВП). Про те варто відзначити, що перетворення Фур'є математично більш складне за дискретне вейвлет-перетворення, а отже потребуватиме більшої кількості операцій для свого здійснення. Також зазначене перетворення не передбачає можливості дослідження локалізованих збурень взагалі [5], що робить його мало ефективним для використання у сучасних системах аналізу віброакустичних сигналів електричних машин. Тоді як ДВП, будучи у першу чергу адаптованим на виявлення саме локалізованих пікових збурень, не передбачає наявності готових інструментів, призначених для сепарації періодичної та аперіодичної складових. Тож, враховуючи сказане, $€$ очевидним, що розробка нових підходів до виявлення періодичних складових вібросигналу на основі ДВП, які можуть викликатися певними дефектами обертових електричних машин, $€$ актуальною науковоприкладною задачею, вирішення якої дозволить суттєво підвищити ефективність роботи систем технічного моніторингу та діагностування.

Mema досліджень. До найбільш поширених причин виникнення вібрації у обертових електричних машинах можна віднести: неврівноваженість ротора, порушення співвісності валів, порушення жорсткості опорної системи, дефекти підшипників, вібрація електричних машин електромагнітного походження тощо. При цьому результуючий вібросигнал на ранніх етапах розвитку дефектів, як правило, характеризується накладанням значної кількості рівноцінних збурюючих чинників, частина з яких має аперіодичний характер [3, 4, 6].

Одним 3 найпоширеніших дефектів обертових електричних машин електро-магнітної природи є асиметрія кіл живлення [3], крайнім випадком якої для трьох і більше фазних машин може бути робота останньої при обриві однієї 3 фаз. Особливістю складової вібрації електромагнітної природи машин змінного струму, зазвичай, $€$ її квазі-гармонічність 3 періодом, що відповідає періоду напруги живлення [3]. Про те, при проведенні стандартного вейвлет-аналізу наявність невеликої асиметрії чи навіть обрив фази в режимі холостого ходу, для якого буде характерним мінімальне значення струму статора, не призводять до появи одиничного яскраво вираженого локального піку в певній частотній смузі, а, отже, за умови відносно невеликих значеннях електромагнітної асиметрії, буде мало помітною при аналізі сигналу, отриманого у результаті дискретного вейвлет перетворення. Тож, враховуючи той факт, що електромагнітна асиметрія, як було зазначено раніше, входить до переліку найбільш поширених дефектів електричних машин, а особливості вібро-акустичного сигналу суттєво обмежують можливість застосування перетворення Фур'є, $\epsilon$ очевидною необхідність формулювання нових методів додаткової оброки сигналу на виході дискретного вейвлет-перетворення 3 митою отримання високоінформативних ознак, що вказували б на наявність зазначеного дефекту.

\section{Виклад основного матеріалу}

досліджень. Одна 3 головних ідей вейвлетперетворення сигналів на різних рівнях декомпозиції (розкладання) полягає в розділенні функцій наближення до сигналу на дві групи: що апроксимує - грубу, з достатньо повільною часовою динамікою змін, і що деталізує - 3 локальною і швидкою динамікою змін на тлі плавної динаміки, з подальшим їх дробленням і деталізацією на інших рівнях декомпозиції сигналів. Це можливо як в часовій, так і в частотній областях представлення сигналів вейвлетами. В цьому випадку базисна вейвлетфункція дозволяє сконцентрувати увагу на тих або інших локальних особливостях аналізованих процесів. При чому, за своєю суттю деталізація неперервного вейвлет-перетворення (НВП) $€$ ні чим іншим, як визначенням функції взаємокореляції між материнською вейвлетфункцією та досліджуваним сигналом, яка випливає 3 математичної моделі такого перетворення [5, 7]:

$$
W(a, \tau)=\int_{-\infty}^{+\infty} f(t) \cdot \psi_{a, \tau}^{*}(t) d t
$$




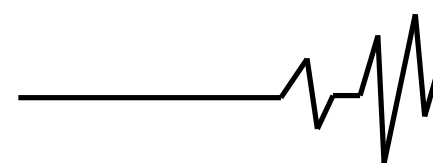

де $W(a, \tau)$ - функція деталізації (результат вейвлет-перетворення); $a$ - параметр масштабу; $T$ - параметр зсуву; $f(t)$ - фрункція, що аналізується; $\psi_{a, \tau}^{*}(t)$ - комплексно спряжена вейвлет-функція.

Враховуючи те, що обчислення при вейвлет-перетворенні здійснюються шляхом зміни масштабу "вікна" аналізу, зсуву його в часі, множення на сигнал та інтегрування по всій осі часу $[7,8]$, фрізичний зміст такого перетворення можна представити як пошук ділянок аналізованої функції у часовій та частотній областях, які за своєю формою будуть корельованими 3 материнською вейвлетфрункцією.

Аналогічний фрізичний зміст зберігається і при ДВП, при здійсненні якого коефіцієнти деталізації можуть бути розраховані наступним чином $[5,8]$ :

$$
d_{k}^{j}=\sum_{n \in Z} g_{n-2 k} \cdot c_{n}^{j+1}
$$

де $d_{k}^{j}-k$-й коефріцієнт деталізації $j-і ̈$ частотної смуги; $g$ - коефіцієнт материнської вейвлет-фрункції; $d^{j+1}$ - апроксимуючий коефріцієнт попередньої частотної смуги, розраховуються наступним чином:

$$
c_{k}^{j}=\sum_{n \in Z} h_{n-2 k} \cdot c_{n}^{j+1}
$$

де $h$ - коефіцієнт масштабуючої функції;

Для старшої частотної смуги у якості апроксимуючих коефріцієнтів використовується часова реалізації досліджуваного сигналу.

Враховуючи кореляційний принцип, закладений у логіку вейвлет-перетворення, не важко дійти висновку, що значення коефіцієнтів окремо узятої частотної смуги будуть, у першу чергу, визначатися співпадінням форми аналізованої функції на досліджуваному масштабі (обраній частотній смузі) 3 фрормою базисної вейвлет-фрункції. При цьому варто зазначити, що, оскільки, вейвлет-перетворення у межах одного масштабу досліджує сигнал усієї часової реалізації з заданим кроком дискретизації т [8], то у випадку наявності періодичної складової у вібросигналі та виборі материнської вейвлетфункції, що буде максимально точно описувати поведінку цієї періодичної складової, варто очікувати серію симетричних додатних та від'ємних піків на усьому часовому діапазоні, протягом якого проводяться спостереження. При чому, додатні піки спостерігатимуться у випадку синфазності шуканого коливання та материнського вейвлету, а від'ємні - при перебуванні останніх у протифразі.

В такому випадку задача реєстрації досліджуваного дефекту може бути розбита на дві підзадачі: підбір материнського вейвлету, який був би максимально наближений до обумовленої неврівноваженістю ротора складової вібросигналу, та розробка критерію, який би давав змогу кількісно оцінити вплив зазначеного коливання на коефіцієнти вейвлет перетворення окремих частотних смуг та був максимально нечутливим до неінформативних сплесків, обумовлених збурюючими силами іншого походження.

Аналіз наведених у літературі описів вібро-акустичних сигналів, обумовлених асиметрією живлення, показує, що зазначений дефект призводить до появи коливань, які містять гармонічну складову, локалізовану на частоті напруги живлення електричної мережі [3, 4]. Зазначений факт обґрунтовує доцільність аналізу частотного діапазону, що включає у себе частоту напруги живлення, та підбір материнського вейвлету, виходячи з ознак, властивих одиничному гармонічному коливанню.

До основних характеристик одиничного гармонічного коливання можна віднести симетрію відносно осі часу, при зміщенні додатної складової на половину періоду уздовж зазначеної осі в довільному напрямку та три нульових стани при розгляді кожного з періодів як незалежних піків, рознесених у часовій області. Не дивлячись на те, що на материнську вейвлет-функцію накладається відоме обмеження:

$$
\int_{-\infty}^{+\infty} \psi(t) d t=0,
$$

переважна більшість відомих вейвлетів $\epsilon$ асиметричними відносно осі часу. Крім цього, усі вейвлети 4-го та вищих порядків передбачають наявність розтягнутих у часовій області вторинних сплесків, що у випадку досліджуваних коливань означатиме накладання залишків одного сплеску на сусідні [9]. Враховуючи це, найбільш подібними до одиничного гармонічного коливання можна вважати вейвлет Хаара та вейвлет Добеши 4-го порядку. Про те варто відзначити, що кожен із них має у своїй структурі суттєві відмінності у порівняння 3 одиничним гармонічним коливанням. А так як дискретні вейвлет-функції зберігають у собі характер зміни їх неперервних аналогів, для покращення візуалізації розглянемо саме неперервний вейвлет Хаара та вейвлет Добеши 4-го порядку. Ïх графічне представлення наведено на рис. 1 [5, 8, 9]. 


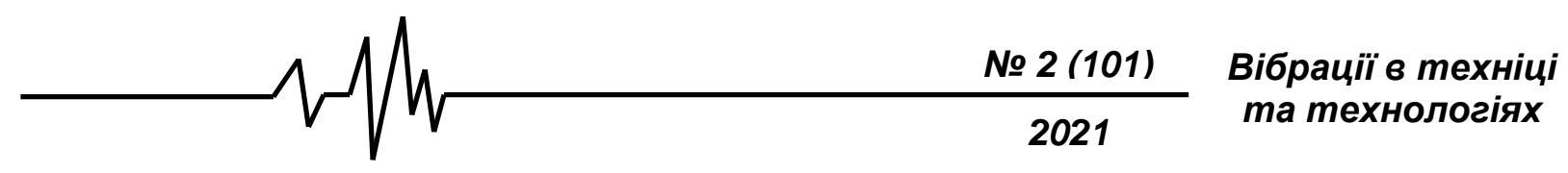

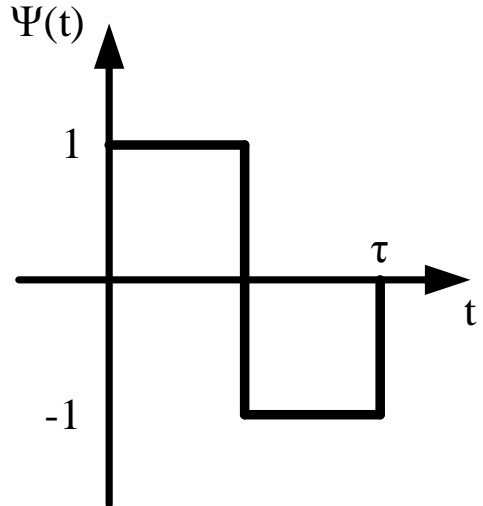

a)

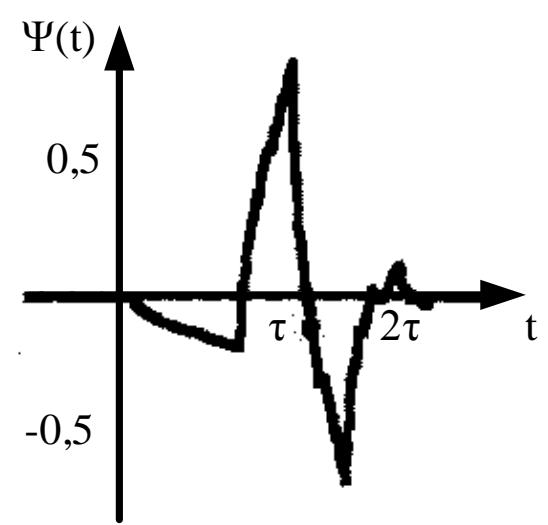

б)

Рис. 1. Материнські вейвлет-функції: а) Хаара, б) Добеши 4-го порядку

Як випливає з рис. 1, вейвлет Хаара характеризується повною $\mathrm{t}$-симетрією з трьома нульовими станами, про те має абсолютно вертикальні фрронти, що $є$ не характерним для гармонічного коливання. Тоді як вейвлет Добеши 4-го порядку характеризується суттєвою $\mathrm{t}$ асиметрією при врахуванні вторинних сплесків, про те основний сплеск $є$ майже t-симетричним та має більш плавні передній та задній фронти, що більшою мірою відповідають досліджуваному сигналові. Враховуючи зазначені обставини $€$ очевидною доцільність експериментального встановлення більш ефрективного 3 наведених вейвлетів, що характеризувався 6 кращою чутливістю відносно досліджуваного дефекту.

$$
\text { Другою задачею, яка була }
$$
сформульована у межах пошуку критерію виявлення електромагнітної асиметрії, $є$ розробка числового критерію аналізу коефріцієнтів вейвлет перетворення. Враховуючи періодичність віброакустичного сигналу, обумовленого наявністю зазначеного дефекту, а також ту обставину, що кожне із гармонічних коливань представляється як окремий сплеск, варто очікувати періодичну зміну значень вейвлет-коефріцієнтів у часовій області в межах смуги частот, що включають у себе частоту мережі живлення. При чому амплітуди таких періодичних зсплесківмін будуть напряму пов'язані 3 ступенем асиметрії живлення. Тож, при виконанні наступної нерівності:

$$
t_{c n}>T_{ж},
$$

де $t_{\text {сп }}$ - тривалість часової реалізації досліджуваного сигналу; $T_{\text {ж }}$ - період напруги живлення.

доцільним $є$ застосування інтегрального підходу до аналізу коефіцієнтів вейвлет -перетворення. Відтак, у якості шуканого критерію може бути використано середньо-квадратичне значення вейвлет-коефіцієнтів досліджуваних частотних смуг у межах часового інтервалу, тривалість якого значно більша за період напруги живлення. Такий підхід дозволить врахувати наявність як додатних так і від'ємних максимумів вейвлет коефіцієнтів у межах досліджуваного часового інтервалу, а також характеризуватиметься пониженою чутливістю до неінформативних збурень, обумовлених аперіодичними збурюючими діями, що можуть виникати в процесі експлуатації електричної машини. Виходячи з сказаного, математично числовий критерій оцінки впливу електромагнітної асиметрії на коефіцієнти вейвлет-перетворення зазначених частотних смуг може бути представлений наступним чином:

$$
k_{\text {деб }}=\frac{1}{n} \sum_{i=1}^{n} d_{i}^{2} \text { при умові } t_{c n}>>T_{\text {ж }} \text {, }
$$

де $n$ - кількість коефіцієнтів вейвлетперетворення досліджуваної частотної смуги; $d_{i}-$ і-й коефріцієнт вейвлет-перетворення досліджуваної частотної смуги.

3 метою підтвердження неведених вище теоретичних міркувань було проведено експериментальне дослідження з використанням асинхронної електричної машини AИM9OLa6Y2.5, номінальною потужністю 0,75 кВт. 3 метою зниження амплітуди електромагнітної складової вібрації зазначене експериментальне дослідження проводилося для режиму холостого ходу. Ємнісний мікромеханічний акселерометр було закріплено на корпусі електричної машини таким чином, щоб вимірювальні осі сенсора були строго перпендикулярними до осі ротора, вісь $\mathrm{X}$ напрямлена строго вертикально, вісь $Y$ - строго горизонтально. Частота дискретизації сигналу становила 232 Гц, довжина часової реалізації досліджуваного сигналу $-2^{14}$ значень.

При перетворенні отриманого сигналу віброприскорення на основі вейвлета Хаара та подальшого розрахунку

середньо- 


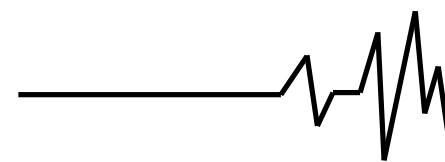

квадратичного вейвлет-коефіцієнтів для кожної із частотних смуг при роботі електричної машини у штатному режимі та обриві фази $A$
№ 2 (101)

2021

було отримано наступні результати, наведені на рис. 2 - рис. 5.

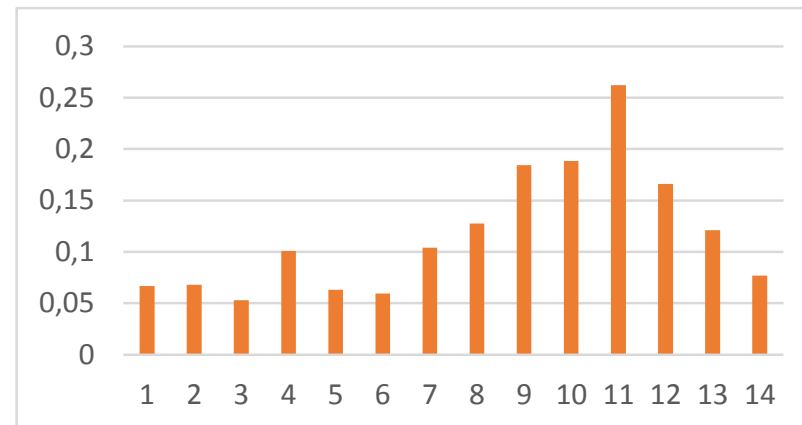

Рис. 2. Залежність середньоквадратичного вейвлет коефіцієнтів Хаара для кожної із частотних смуг вібросигналу по осі $X$ при роботі електродвигуна у штатному режимі

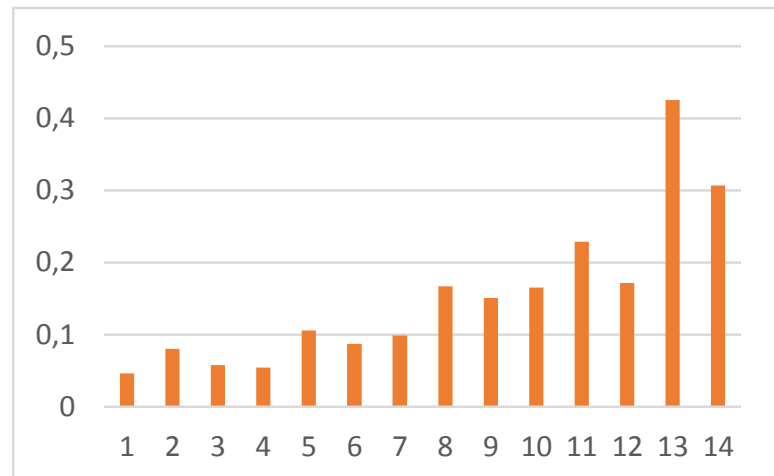

Рис. 3. Залежність середньоквадратичного вейвлет коефіцієнтів Хаара для кожної із частотних смуг вібросигналу по осі $\mathrm{X}$ при обриві фази $\mathrm{A}$

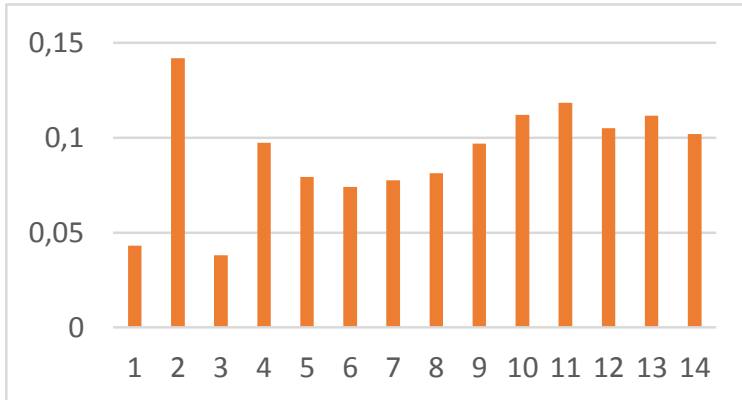

Рис. 4. Залежність середньоквадратичного вейвлет коефіцієнтів Хаара для кожної із частотних смуг вібросигналу по осі Y при роботі електродвигуна у штатному режимі

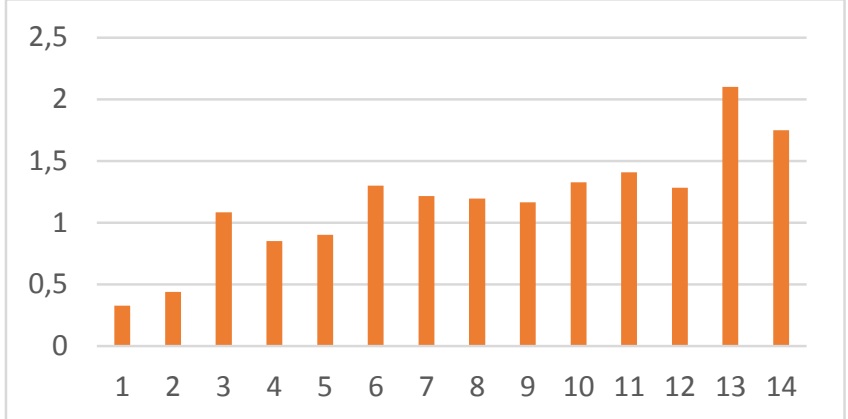

Рис. 5. Залежність середньоквадратичного вейвлет коефіцієнтів Хаара для кожної із частотних смуг вібросигналу по осі Ү при обриві фази А 


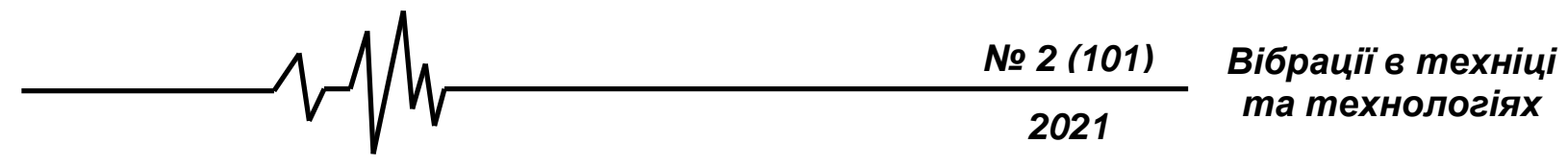

Також було виконано аналогічне перетворення отриманого вібросигналу за допомогою вейвлета Добеши 4-го порядку.
Результати розрахунку наведені на рис. 6 рис. 9.

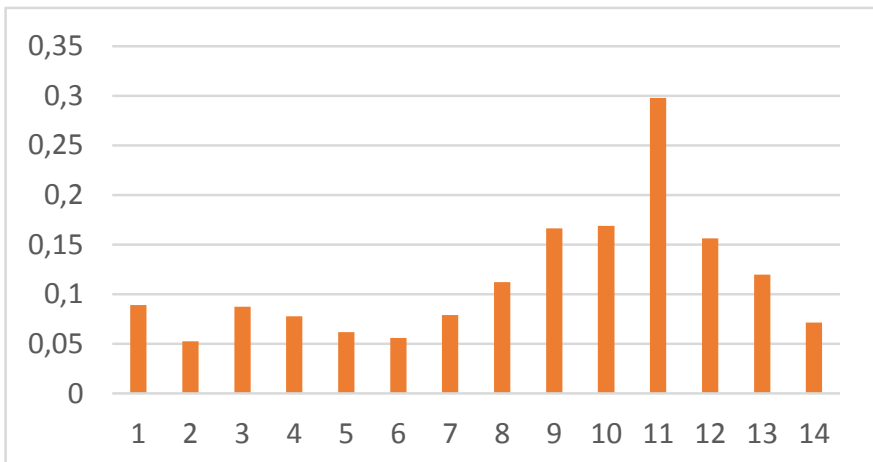

Рис. 6. Залежність середньоквадратичного вейвлет коефіцієнтів Добеши 4-го порядку для кожної із частотних смуг вібросигналу по осі $X$ при роботі електродвигуна $y$ штатному режимі

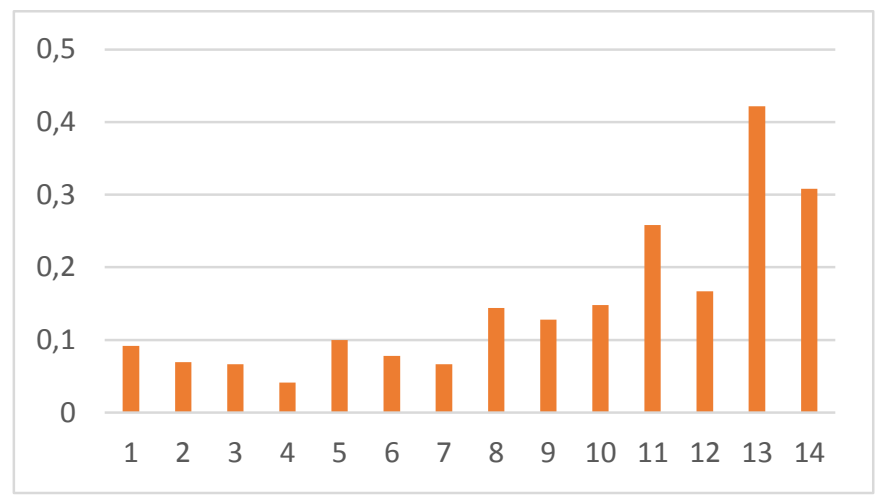

Рис. 7. Залежність середньоквадратичного вейвлет коефіцієнтів Добеши 4-го порядку для кожної із частотних смуг вібросигналу по осі $X$ при обриві хази $A$

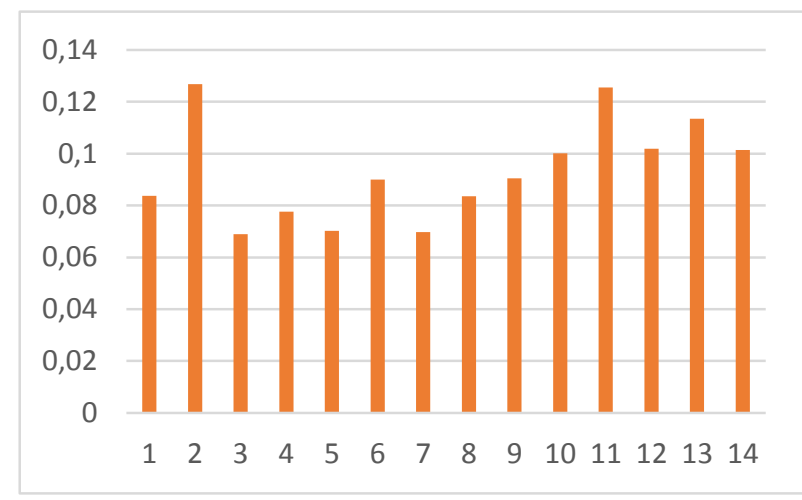

Рис. 8. Залежність середньоквадратичного вейвлет коефіцієнтів Добеши 4-го порядку для кожної із частотних смуг вібросигналу по осі Ү при роботі електродвигуна у штатному режимі 

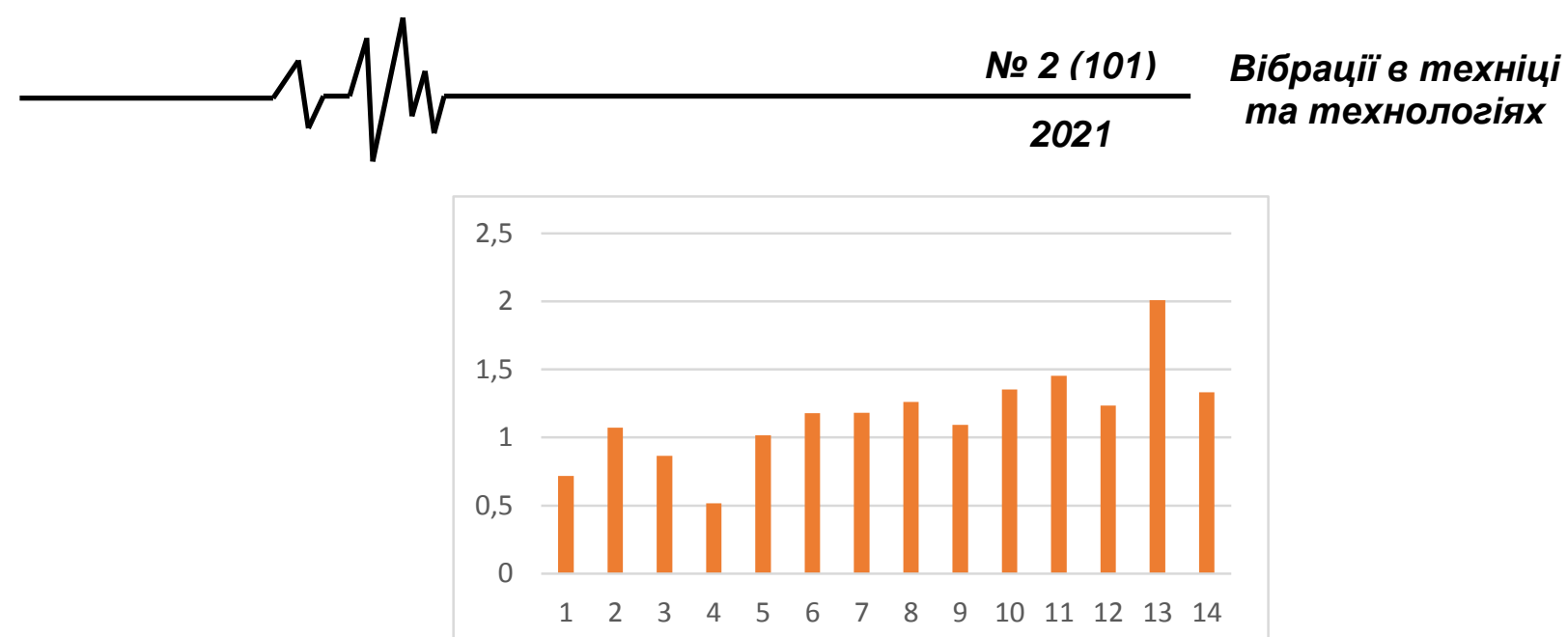

Рис. 9. Залежність середньоквадратичного вейвлет коефіцієнтів Добеши 4-го порядку для кожної із частотних смуг вібросигналу по осі Ү при обриві фази А

Як випливає 3 аналізу залежностей, наведених на рис. 2 - рис. 9, найбільш інфрормативними для виявлення асиметрії живлення, як і очікувалося, є частотна смуга, що відповідає частоті напруги живлення електромережі 50 Гц (13 частотна смуга). Порівняння ж результатів, отриманих при розкладанні сигналу на основі вейвлету Хаара та вейвлету Добеши 4-го порядку показали, що обидва вейвлета характеризуються приблизно однаковою достатньо високою чутливістю до наявності досліджуваного дефекту. Тож, враховуючи той факт, що перетворення на основі материнської вейвлет-фрункції Хаара $\epsilon$ математично більш простим (потребує меншої кількості математичних операцій) $[5,8,9]$, можна зробити висновок, що використання саме останнього є більш ефективним для виявлення наявності зазначеного дефекту.

Висновки. 1. Встановлено, що виявлення дефекту асиметрії живлення 3 використанням вейвлет-перетворення часової реалізації віброакустичного сигналу доцільно здійснювати 3 використанням материнської вейвлет-функції Хаара, що забезпечує поєднання високого ступеня спорідненості материнського вейвлету з формою зміни вібросигналу за рахунок асиметрії живлення та відносної простоти такого перетворення.

2. Показано, що при виявлені асиметрії живлення доцільно здійснювати аналіз поведінки вейвлет коефіцієнтів частотної смуги, що включає у себе частоту напруги живлення електричної машини. Оскільки вплив зазначеного дефекту на інші частотні смуги буде мінімальним, то аналіз поведінки їх коефіцієнтів вейвлет перетворення 3 метою виявлення зазначеного дефекту $€$ неефективним.

3. Запропоновано числовий критерій оцінки впливу асиметрії живлення на коефіцієнти вейвлет перетворення у вигляді середньо квадратичного значення вейвлет коефіцієнтів інформативної частотної смуги при дослідженні часового інтервалу, який значно перевищує період напруги живлення електричної машини. Показано, що зазначений критерій має понижену чутливість до впливу неінформативних одиничних збурень, які можуть виникати в процесі роботи електричної машини.

\section{Список використаних джерел}

1. Левицький А. C. Підвищення ефективності діагностування потужних гідроагрегатів за рахунок застосування ємнісних вимірювачів параметрів механічних дефектів. Гідроенергетика України. 2010. № 4, 10-13.

2. Hraniak V. F., Kukharchuk V. V., Kucheruk V. Y. and other. Using instantaneous crosscorrelation coefficients of vibration signals for technical condition monitoring in rotating electric power machine. Bulletin of the Karaganda University. «Physics» series. 2018. № 1, 72-80

3. Ширман А. Р., Соловьев А. Б. Практическая вибродиагностика и мониторинг состояния механического оборудования. Москва: Машиностроение, 1996 - 276 с.

4. Кухарчук В. В., Кацив С. Ш., Граняк В. Ф. та ін. Дискретні вейвлет-перетворення в діагностуванні гідроагрегатів. Монографрія. Вінниця: ВНТ, 2018. - 112 с.

5. Воробъёв В. И., Грибунин В. Г. Теория и практика вейвлет-преобразования. С.-Петербург: ВСУ, 1999. - 204 c.

6. Киселёв Ю. В., Киселев Д. Ю., Тиц С. Н. Вибрационная диагностика систем и конструкций авиационной техники. Учебник. Самара: Изд-во Самар, гос. аэрокосм, ун-та, 2012. - 207 с.

7. Broughton S. A., Bryan K. Discrete fourier analysis and wavelets : applications to signal and image processing. New Jersey: John Wiley \& Sons, Inc., 2008. - 355 p.

8. Polikar $R$. The Wavelet tutorial. Roma: Rowan University, College of Engineering Web Servers, 2001. $-79 \mathrm{p}$.

9. Addison P. S. The Illustrated Wavelet Transform Handbook. Introductory Theory and Applications in Science, Engineering, Medicine and Finance. Edinburgh: Napier University, 2002 - 359 p. 


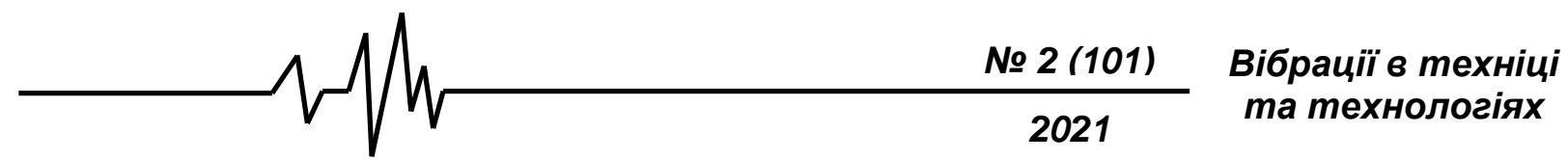

\section{References}

1. Levitsky A.S. ( 2010). Improving the efficiency of diagnosing powerful hydraulic units through the use of capacitive meters for the parameters of mechanical defects. Hydropower of Ukraine. [in Ukrainian].

2. Hraniak V. F., Kukharchuk V. V., Kucheruk V. Y. and other. (2018) Using instantaneous cross-correlation coefficients of vibration signals for technical condition monitoring in rotating electric power machine. Bulletin of the Karaganda University. «Physics» series. [in English].

3. Shirman A.R., Solovyov A.B. (1996) Practical vibration diagnostics and monitoring of mechanical equipment. Moscow: Mashinostroenie. [in Russian].

4. Kukharchuk V.V, Katsiv S. Sh., Granyak VF and others. (2018)Discrete wavelet transforms in the diagnosis of hydraulic units. Monograph. Vinnytsia. [in Ukrainian].

5. Vorobyov V.I., Gribunin V.G. (1999) Theory and practice of wavelet transform. St. Petersburg: VSU. [in Russian].

6. Kiselyov Y.U., Kiselyov D. Yu., Titz S.N. (2012) Vibration diagnostics of systems and structures of aviation equipment. Textbook. Samara: Samar Publishing House, Gos. Aerospace, University. [in Russian].

7. Broughton S. A., Bryan K. (2008) Discrete fourier analysis and wavelets : ap-plications to signal and image processing. New Jersey: John Wiley \& Sons, Inc. [in English].

8. Polikar R. (2001) The Wavelet tutorial. Roma: Rowan University, College of Engineering Web Servers. [in English].

9. Addison P. S. (2002) The Illustrated Wavelet Transform Handbook. Introduc-tory Theory and Applications in Science, Engineering, Medicine and Finance. Edin-burgh: Napier University. [in English].

\section{ИСПОЛЬЗОВАНИЕ ДИСКРЕТНОГО ВЕЙВЛЕТ- АНАЛИЗА ВИБРО-АКУСТИЧЕСКИХ СИГНАЛОВ ДЛЯ ОПРЕДЕЛЕНИЯ НАЛИЧИЯ АСИММЕТРИИ ПИТАНИЯ ВРАЩАЮЩИХСЯ ЭЛЕКТРИЧЕСКИХ МАШИН ПЕРЕМЕННОГО ТОКА}

В работе показано, что среди существующих достаточно описанных и изученных подходов, пригодных для анализа временной реализации вібосигнала, который может быть получен при работе реальной электрической машины, можно выделить преобразования Фурье и дискретное вейвлетпреобразования. Анализ приведенных в литературе описаний вибро-акустических сигналов, обусловленных асимметрией питания, показывает, что указанный дефект приводит к появлению колебаний, которые содержат гармоническую составляющую, локализированную на частоте питающего напряжения электрической сети. Указанный факт обосновывает целесообразность анализа частотного диапазона, который включает в себя частоту напряжения питания, и подбор материнского вейвлета, исходя из признаков, присущих единичному гармоничному колебанию.

Предложен способ обнаружения дефекта асимметрии питания вращающихся электрических машин переменного тока с помощью дискретного вейвлет-преобразования вибро-акустического сигнала. Установлено частотную полосу, которую целесообразно анализировать с целью выявления наличия указанного дефекта.

Установлено, что обнаружение дефекта асимметрии питания с использованием вейвлетпреобразования временной реализации виброакустического сигнала целесообразно осуществлять с использованием материнской вейвлет-функции Хаара, что обеспечивает сочетание высокой степени родства материнского вейвлета с формою изменения вибрации за счет внесённой асимметрии и относительной простоты такого преобразования.

$\begin{array}{ccc}\text { Показано, что при обнаружении } \\ \text { асимметрии } & \text { питания } & \text { целесообразно }\end{array}$ осуществлять анализ поведения вейвлеткоэффициентов частотной полосы, которая включает в себя частоту напряжения питания электрической машины. Поскольку влияние указанного дефекта на другие частотные полосы будет минимальным, то анализ поведения их коэфффициентов вейвлет-преобразования с целью выявления наличия указанного дефекта является неэффрективным.

Предложено числовой критерий оценки влияния асимметрии питания на коэффрициенты вейвлет преобразования в виде средне квадратического значения вейвлеткоэффициентов информативной частотной полосы при исследовании временного интервала, значительно превышающего период напряжения питания электрической машины. Показано, что данный критерий имеет сниженную чувствительность к воздействию неинформативных единичных возмущений, которые могут возникать в процессе работы электрической машины.

Ключевые слова: электрическая машина, асимметрия, дефект, всплеск, вейвлетпреобразования.

\section{THE USE OF DISCRETE WAVELET ANALYSIS OF VIBRO-ACOUSTIC SIGNALS TO DETECT THE POWER SUPPLY ASYMMETRY OF ROTATING ACCOMPANYING ELECTRIC MACHINES}

The work shows that among the existing sufficiently described and studied approaches that are 


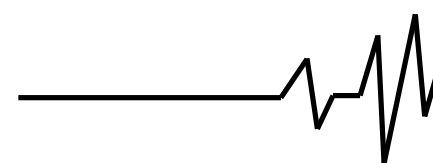

suitable for analyzing the temporal realization of a vibosignal, which can be obtained during the operation of a real electric machine, one can single out Fourier transforms and discrete wavelet transformations. An analysis of the descriptions of vibro-acoustic signals given in the literature, caused by the asymmetry of the power supply, shows that this defect leads to the appearance of oscillations that contain a harmonic component localized at the frequency of the supply voltage of the electrical network. This fact justifies the expediency of analyzing the frequency range, which includes the frequency of the supply voltage, and the selection of the mother wavelet, based on the features inherent in a single harmonic oscillation.

A method for detecting a defect in the asymmetry of power supply to rotating electric machines of alternating current using a discrete wavelet transformation of a vibro-acoustic signal is proposed. The frequency band has been established, which is advisable to analyze in order to identify the indicated defect.

It was found that the detection of a power asymmetry defect with the use of the wavelet transform of the temporal realization of the vibroacoustic signal is advisable to carry out using the Haar maternal wavelet function, which provides a combination of a high degree of affinity of the maternal
№ 2 (101)

2021
Вібрації в техніці та технологіях wavelet with the form of vibration change due to the introduced asymmetry and relative the simplicity of such a transformation.

It is shown that when detecting power asymmetry, it is advisable to analyze the behavior of the wavelet coefficients of the frequency band, which includes the frequency of the supply voltage of the electric machine. Since the influence of the indicated defect on other frequency bands will be minimal, the analysis of the behavior of their wavelet transform coefficients in order to identify the indicated defect is ineffective.

A numerical criterion for assessing the influence of power asymmetry on the wavelet transform coefficients is proposed in the form of the mean square value of the wavelet coefficients of the informative frequency band in the study of the time interval, which significantly exceeds the period of the supply voltage of the electric machine. It is shown that this criterion has a reduced sensitivity to the impact of non-informative single disturbances that may arise during the operation of an electric machine. Keywords: electric machine, rotor unbalance, defect, burst, wavelet transform.

Key words: electric machine, asymmetry, defect, burst, wavelet transform.

\section{Відомості про авторів}

Граняк Валерій Федорович - кандидат технічних наук, доцент, доцент кафедри «Електротехніки, електроенергетики та електромеханіки» Вінницького національного аграрного університету (вул. Сонячна, 3, м. Вінниця, Україна, 21008, e-mail: titanxp2000@ukr.net).

Гайдамак Олег Леонідович - кандидат технічних наук, доцент, доцент кафедри «Електротехніки, електроенергетики та електромеханіки» Вінницького національного аграрного університету (вул. Сонячна, 3, м. Вінниця, Україна, 21008, e-mail: haidamak@vsau.vin.ua).

Граняк Валерий Федорович - кандидат технических наук, доцент, доцент кафедры «Электротехники, электроэнергетики и электромеханики» Винницкого национального аграрного университета (ул. Солнечная, 3, г.. Винница, Украина, 21008, e-mail: titanxp2000@ukr.net).

Гайдамак Олег Леонидович - кандидат технических наук, доцент, доцент кафредры «Электротехники, электроэнергетики и электромеханики» Винницкого национального аграрного университета (ул. Солнечная, 3, г.. Винница, Украина, 21008, e-mail: haidamak@vsau.vin.ua) .

Graniak Valeriy Fedorovich - Candidate of Science (Engineering), Associate Professor, Associate Professor of the Department of Power engineering, electrical engineering and electromechanics of Vinnitsa National Agrarian University . (3 Soniachna St., Vinnitsa, Ukraine, 21008, e-mail: titanxp2000@ukr.net)

Gaidamak Oleg Leonidovich - Candidate of Science (Engineering), Associate Professor, Associate Professor of the Department of Power engineering, electrical engineering and electromechanics of Vinnitsa National Agrarian University . (3 Soniachna St., Vinnitsa, Ukraine, 21008, e-mail: haidamak@vsau.vin.ua) 